\title{
ФОРМУВАННЯ ДОХОДІВ МІСЦЕВИХ БЮДЖЕТІВ В УМОВАХ БЮДЖЕТНОЇ ДЕЦЕНТРАЛІЗАЦІЇ
}

\section{FORMATION OF LOCAL BUDGET REVENUES IN CONDITIONS OF BUDGETARY DECENTRALIZATION}

\begin{abstract}
у статmі розглянуто особливості фрормування місцевих бюджетів України в умовах бюджетної децентралізації. Досліджено теоретичні засади бюджетної децентралізації та визначено їі роль у здійсненні трансформаційних процесів у державі в сучасних умовах. Проаналізовано сучасні тендениі формування дохідної частини місцевих бюджетів України, на основі чого виявлено значну фріскальну роль податкових надходжень та потребу у зростанні обсягів місцевих податків і зборів. Визначено вплив процесів децентралізації на механізм орормування доходів та обгрунтовано необхінність іi подальшого впровадження для забезпечення есрективного соціально-економічного розви тку регіонів та максимального задоволення суспільними благами та послугами населення. На основі окреслених проблем процесу фрормування дохідної частини місцевих бюджетів визначено пріоритетні напрямки його вдосконалення в умовах бюджетної децентралізації.

Ключові слова: бюджет, бюджетна система, бюджетна децентралізація, місцеві бюджети, доходи місцевих бюджетів, податкові надходження, міжбюджетні транс ферти, органи місцевого самоврядування.
\end{abstract}

В статье рассмотрены особенности фрормирования местных бюджетов Украины в условиях бюджетной децентрализации. Исследованы теоретические основы бюджетной децентрализации и определена ее роль в осуществлении транссрормационных процессов в государстве в современных условиях. Проанализированы современные тенденции формирования доходной части местных бюджетов Украины, на основе чего выявлено значительную фрискальную роль налоговых поступлений и необходи мости в росте объемов местных налогов и сборов. Определено влияние прочессов децентрализации на механизм формирования доходов и обоснована необходимость их дальнейшего внедрения для обеспече ния эфрективного социально-экономического развития регионов и максимального удовлетворения общественными благами и услугами населения. На основе обозначенных проблем процесса фрормирования доходной части местных бюджетов определены приоритетные направления его совершенствования в условиях бюджетной децентрализации.

Ключевые слова: бюджет, бюджетная система, бюджетная децентрализация, местные бюджеты, доходы местных бюд жетов, налоговые поступления, межбюджетные трансфрерты, органы местного самоуправления.

The article deals with peculiarities of formation of local budgets of Ukraine under conditions of budgetary decentralization. The theoretical foundations of budgetary decentralization have been investigated and the discussion aspects of this concept have been considered. The role of budgetary decentralization in the implementation of transformation processes in the state in modern conditions is determined. The modern tendencies of formation of the revenue part of local budgets of Ukraine are analyzed. Based on the analysis of the formation of local budget revenues of Ukraine for 2016-2018, a significant share of intergovernmental transfers in the total revenue structure was revealed, which indicates a low degree of participation of local self-government in solving problems of regional development. The fiscal role of tax revenues in the formation of the revenue base has been determined and the need for increasing local taxes and levies has been emphasized to further strengthen the own resource potential of local governments. As a result of the analysis, the article identifies the impact of decentralization processes on the mechanism of revenue generation of local budgets, emphasizing its main advantages. The necessity of further implementation of the decentralization reform in the country is justified in order to ensure the effective socio-economic development of the regions and to maximize satisfaction with the public goods and services of the population. The necessity of further extension of powers of local selfgovernment bodies, affirmation of their financial independence, stimulation to increase their own income base to fulfill the fully given powers in the context of achievement of set goals and tasks in accordance with the regional development program is emphasized. Emphasis has been placed on strengthening the role of local budgets in ensuring the financial autonomy of local authorities and the need for a series of interrelated measures to further the successful implementation of budgetary decentralization. On the basis of the outlined problems of the process of formation of the revenue part of local budgets, priority directions of its improvement under conditions of budgetary decentralization were determined.

Key words: budget, budget system, budget decentralization, local budgets, local budget revenues, tax revenues, intergovernmental transfers, local governments.

Постановка проблеми. На сучасному етапі розвитку України актуальним постає питання забезпечення ефективного економічного й соціального розвитку регіонів в контексті впровадження процесів бюджетної децентралізації в державі. Дієвими важелями успішної реалізації ресорми децентралізації $€$ інструменти бюджетної політики, що спрямовані на вирішення стратегічних та поточних завдань щодо утвердження фрінансової незалежності органів місцевого самоврядування, зміцнення фрінансової стійкості місцевих бюджетів, створення сприятливих умов для розвитку місцевої інфрраструктури тощо. При цьому особливої актуалізації для розв'язання зазначених завдань набувають питання, що стосуються фрормування належної ресурсної бази для виконання місцевими органами влади, покладених на них фуннкцій, досягнення основних цілей розвитку регіону, окреслених у відповідних програмах, для максимального задоволення якісними суспільними благами безпосередньо населення.

Проте, незважаючи на розпочатий у 2014 році в Україні курс на децентралізацію, залишаються невирішеними проблеми фрінансового забезпечення органів місцевого самоврядування, постійної нестачі фрінансових ресурсів, нестабільності 
дохідних джерел місцевих бюджетів та їх залежність від бюджетних трансфертів, а також низький рівень забезпечення локальними суспільними благами, тощо. Тому подальше застосування місцевою владою дієвих заходів щодо модернізації фрормування місцевих бюджетів в умовах бюджетної децентралізації сприятиме активізації реформи та ефективному розвитку інституту місцевого самоврядування.

Аналіз останніх досліджень і публікацій. Питанням фрункціонування місцевих бюджетів, формуванню їх дохідної частини присвячені праці таких вітчизняних науковців, як: Буковинського С., Василика О., Дем'янишина В., Дем'янюк А., Кириленко О., Кравченка В., Кульчицького М., Лободіної 3., Луніної І., Опаріна В., Павлюк К., Письменного В., Федосова В., Юрія С. та ін. Проте в сучасних умовах реалізації бюджетної ресорми актуальним постає дослідження впливу процесів децентралізації на фрормування доходів місцевих бюджетів та окреслення пріоритетних напрямів розвитку місцевих бюджетів в контексті модернізації порядку фрормування їхніх дохідних джерел.

Постановка завдання. Метою дослідження $€$ визначення впливу бюджетної децентралізації на процес фрормування доходів місцевих бюджетів та обґрунтування необхідності подальшого його рефрормування в сучасних умовах.

Виклад основного матеріалу дослідження. В сучасних умовах питання бюджетної децентралізації та ефрективної організації міжбюджетних відносин в Україні постають першочерговими, оскільки $€$ визначальним чинником фрінансової незалежності та життєздатності місцевих органів влади. Саме децентралізація процесів прийняття управлінських рішень сприяє збільшенню можливості місцевої влади щодо участі у розвитку відповідної території, а відповідно бюджетна децентралізація сприяє забезпеченню суспільними послугами населення шляхом чіткого узгодження видатків органів влади різних рівнів відповідно до місцевих потреб й уподобань.

Зважаючи на дискусійність поглядів вітчизня них науковців щодо визначення сутності та видів децентралізації, одностайним їхнім твердженням $€$ те, що визначальна роль у реалізації політики децентралізації влади країни належить саме процесу, який пов'язаний із розподілом фрункцій і повноважень між державними та місцевими органами влади для забезпечення громадян країни необхідними суспільними благами та послугами, а також розмежування фрінансових ресурсів в обсязі, достатньому для фрінансування власних повноважень органів місцевого самоврядування. В контексті зазначеного, органи місцевого самоврядування досягають достатнього для вирішення власних самоврядних повноважень рівня фрінансової самостійності.
Щодо визначення у фрінансовій науці поняття «бюджетна децентралізація», зазначимо, що даний процес характеризує розподіл видаткових повноважень між рівнями бюджетної системи, визначає особливості формування доходів місцевих бюджетів, а також характеризує систему міжбюджетних відносин. Тобто бюджетна децентралізація охоплює саме процес фрормування та використання фрінансових ресурсів місцевих бюджетів.

Так, у Фінансовому словнику за редакцією Загороднього А.Г., Вознюка Г.Л., Смовженко Т.С. бюджетна децентралізація тлумачать як «процес передання центральною владою частини прав, компетенцій, відповідальності і фрінансових ресурсів у бюджетній сорері місцевим органам виконавчої влади та місцевого самоврядування» [3]. В результаті даного процесу зростає відповідно частка місцевих бюджетів у Зведеному бюджеті України.

Так, на думку О. Сунцової, бюджетна децентралізація - це спосіб виміру величини переходу національної економіки від адміністративно-командної до ринкової, і яка є доцільною за умови досягнення розумного оптимуму між фрормуванням доходів місцевих бюджетів та фрінансуванням делегованих повноважень [14].

C. Серьогін тлумачить бюджетну децентралізацію як перенесення надходження доходів або здійснення витрат грошових коштів на більш низький рівень уряду при одночасному збереженні фрінансової відповідальності [9].

У більш широкому розумінні визначає вищезазначене поняття І. Усков, зокрема вважає, що дана деорініція передбачає забезпечення місцевих органів влади достатнім обсягом фрінансових ресурсів для розвитку власного фрінансового потенціалу територій, реалізації інвестиційних програм, стимулювання підприємницької активності на рівні адміністративно-територіальних одиниць [15].

Г. Лопушняк, 3. Лободіна, М. Ливдар розглядають фріскальну децентралізацію як «механізм забезпечення фрінансової стабільності місцевих бюджетів та підвищення ефективності розподілу і використання бюджетних коштів» [8].

Тому бюджетно-срінансова децентралізація вважається всеохоплюючим процесом рефрормування бюджетної системи держави, що базується на принципах фрінансової децентралізації і спрямований на зростання та утвердження фрінансової незалежності органів місцевого самоврядування.

Адже, як справедливо зазначає О.П. Кириленко, головною ознакою фрінансової незалежності органів місцевого самоврядування $€$ «володіння і самостійне розпорядження фрінансовими ресурсами, обсяг яких відповідає фрункціям і завданням, що покладаються на ці органи» [7]. Це свідчить про необхідність забезпечення фрінансовими ресурсами як власних, так і делегованих повноважень органів місцевої влади. 
Тому варто зазначити, що даний процес сприяє підвищенню як якості, так і есрективності надання суспільних послуг за рахунок наближення органів влади безпосередньо до населення, оскільки саме на місцеві органи влади покладається відповідальність за прийняття рішень 3 питань формування і використання фрінансових ресурсів.

32014 року в Україні розпочато проведення ресрорми бюджетної децентралізації, метою якої $€$ підвищення фрінансової незалежності органів місцевого самоврядування та розширення їхніх повноважень. Тому в умовах курсу на децентралізацію бюджетної системи пильна увага науковців та практиків приділяється питанням фрормування доходів місцевих бюджетів.

В контексті реалізації реформи децентралізації в Україні, що базується на Стратегії сталого розвитку «Україна - 2020» [11], Законі України «Про добровільне об'єднання територіальних громад» [10], Концепції ресрормування місцевого самоврядування та територіальної організації влади в Україні [12] й інших нормативно-правових актів, передбачено оптимізацію розподілу повноважень між органами влади різних рівнів, виходячи $з$ принципу субсидіарності та при стабільних джерелах доходів й раціональному використанні накопиченого потенціалу, і в результаті досягнення фрінансової спроможності регіонів.

Доцільно звернути увагу і на положення Бюджетного кодексу України, що стали законодавчим підґрунтям для стимулювання територіальних громад до об'єднання з метою підвищення їхньої спроможності - об'єднані громади наділяються такими ж повноваженнями та ресурсами, як міста обласного значення [1].

В контексті бюджетної децентралізації з метою підвищення фрінансової спроможності місцевих бюджетів було внесено зміни і щодо механізму формування доходів місцевих бюджетів. Зокрема в частині внесених змін відбулося розширення переліку джерел наповнення дохідної частини місцевих бюджетів.

Так, відповідно до бюджетного законодавства та регіональних перспективних планів формування територій об'єднані громади одержують значні переваги щодо фрінансового і ресурсного забезпечення: 60\% податку на доходи фрізичних осіб; прямі міжбюджетні відносини 3 державним бюджетом; державні субвенції; участь у фрінансовому вирівнюванні; розширений перелік трансфрертів соціального характеру; повноцінні видаткові повноваження; доступ до місцевих зовнішніх запозичень; повноваження у ссрері архітектурнобудівельного контролю; право безпосереднього надання всіх адміністративних послуг через власні інституції; повноваження формувати органи громадського правопорядку. Крім того, об'єднані територіальні громади можуть отримувати державну фрінансову підтримку у вигляді субвенцій із державного бюджету за рахунок коштів Державного фонду регіонального розвитку на фрормування інфрраструктури згідно з планом соціальноекономічного розвитку громади.

Аналізуючи дохідну частину Зведеного бюджету України без урахування міжбюджетних трансорертів відмітимо позитивну тенденцію до зростання у його структурі все ж таки доходів Державного бюджету України. У 2016 році вони склали 612103 млн. грн. або 78,19\% від суми доходів зведеного бюджету України, у 2017 році 787297 млн. грн. або 77,43\%, а у 2018 році цей показник становив 929262 млн. грн. - 77,99\% [13]. Відповідно доходи місцевих бюджетів України у відсотковому співвідношенні до загального обсягу дохідної частини Зведеного бюджету України не перевищують показника 22,57\%, що свідчить про низький ступінь участі місцевого самоврядування в розв'язанні проблем розвитку регіонів (табл. 1).

Аналіз фрормування дохідної частини місцевих бюджетів за результатами вже проведеної низки заходів в контексті реалізації ресрорми бюджетної децентралізації, незважаючи на негативні її аспекти на стадії прийняття змін, свідчить вже і про позитивні результати.

Загалом за 2016-2018 роки спостерігається зростання суми доходів місцевих бюджетів України. У 2016 році дохідна частина місцевих бюджетів становила 170645 млн. грн., у 2017 році цей показник зріс на 58846 млн. грн. і склав 229491 млн. грн., у 2018 році спостерігалось таке зростання на 32760 млн. грн., і відповідно доходи склали 262251 млн. грн.

Склад та структура доходів зведеного бюджету України

Таблиця 1

(без урахування міжбюджетних трансфертів) за 2016-2018 рр.

\begin{tabular}{|c|c|c|c|c|c|c|}
\hline \multirow{3}{*}{ Вид бюджету } & \multicolumn{6}{|c|}{ Роки } \\
\hline & \multicolumn{2}{|c|}{2016} & \multicolumn{2}{|c|}{2017} & \multicolumn{2}{|c|}{2018} \\
\hline & млн. грн. & питома вага,\% & млн. грн. & питома вага,\% & млн. грн. & питома вага,\% \\
\hline Державний бюджет & 612103 & 78,19 & 787297 & 77,43 & 929262 & 77,99 \\
\hline Місцеві бюджети & 170645 & 21,81 & 229491 & 22,57 & 262251 & 22,01 \\
\hline Зведений бюджет & 782748 & 100 & 1016788 & 100 & 1191514 & 100 \\
\hline
\end{tabular}

Джерело: складено автором на основі [13] 
У структурі доходів місцевих бюджетів України найбільшу частку у загальному обсязі становлять осріційні транссрерти - близько 50\% впродовж аналізованого періоду. Питома вага податкових надходжень коливається від 40,13\% у 2016 році до $40,54 \%$ у 2018 році. Незначна фіскальна роль відводиться такій статті доходів місцевих бюджетів України як неподаткові надходження та доходи від операцій з капіталом, оскільки вони складають найменшу суму від загального обсягу доходів. У 2016 році питома вага неподаткових надходжень становила 5,94\% або 21757 млн. грн., у 2016 р. вона зменшилась на 0,28\% і становила 5,66\% 25969 млн. грн., і у 2018 році відбулося зменшення до показника 5,14\% (або 29129 млн. грн.) від загальної суми доходів місцевих бюджетів України. Щодо доходів від операцій з капіталом, то їхня частка від загальної суми доходів склала близько 0,55\% за аналізований період (табл. 2).

Зміни, які були внесені до Податкового кодексу посприяли зростанню дохідної частини місцевих бюджетів завдяки зарахуванню до них відповідних податків, зборів та інших платежів.

Загалом у 2016-2018 рр. помітне збільшення податкових надходжень місцевих бюджетів України із 146902 млн. грн. до 229815 млн. грн. Щодо структури податкових надходжень місцевих бюджетів України найбільшу частку складає пода- ток на доходи фрізичних осіб (ПДФО): у 2016 році $53,76 \%$ (78971 млн. грн.), у 2017 році $-55,05 \%$ (110653 млн. грн.) і у 2018 році - 59,02\% (135647 млн. грн.). Другим найбільшим у відсотковому співвідношенні щодо загального показника податкових надходжень $€$ місцеві податки та збори, у 2016 році вони склали 42261 млн. грн. або $28,77 \%$, у 2017-52587 млн. грн. або $26,16 \%$, а у 2018 році - 58902 млн. грн. або 25,63\%. Наступними за обсягом $€$ внутрішні податки на товари та послуги, які коливаються в межах від 5,93\% до 7,92\% (табл. 3). Інші види податків, такі як податок на прибуток підприємств, рентна плата та плата за використання інших природніх ресурсів та інші податки та збори, що мають мізерну фріскальну роль у фрормуванні доходів місцевих бюджетів, також зростають упродовж аналізованого періоду.

Так, відмітимо, що транссоормаційні процеси загалом показали позитивний вплив на фрормування дохідної частини місцевих бюджетів, що відповідно відображає щорічне її зростання і не лише за рахунок міжбюджетних трансорертів, але і завдяки збільшенню власних надходжень. Проте не виключається все ще досить висока залежність місцевих бюджетів від обсягів наданих з державного бюджету трансорертів, що складають близько половини надходжень. Це свідчить про значну ще їх залежність від державного бюджету, що

Склад та структура доходів місцевих бюджетів України за 2016-2018 рр.

\begin{tabular}{|c|c|c|c|c|c|c|}
\hline \multirow{3}{*}{ Доходи } & \multicolumn{6}{|c|}{ Рік } \\
\hline & \multicolumn{2}{|c|}{2016} & \multicolumn{2}{|c|}{2017} & \multicolumn{2}{|c|}{2018} \\
\hline & млн. грн. & $\begin{array}{c}\text { питома } \\
\text { вага,\% }\end{array}$ & млн. грн. & $\begin{array}{c}\text { питома } \\
\text { вага,\% }\end{array}$ & млн. грн. & $\begin{array}{c}\text { питома } \\
\text { вага,\% }\end{array}$ \\
\hline Податкові надходження & 146902 & 40,13 & 201005 & 43,82 & 229815 & 40,54 \\
\hline Неподаткові надходження & 21757 & 5,94 & 25969 & 5,66 & 29129 & 5,14 \\
\hline Доходи від операцій з капіталом & 1986 & 0,54 & 2517 & 0,55 & 3308 & 0,58 \\
\hline Офріційні трансфрерти & 195395 & 53,39 & 229491 & 49,97 & 304672 & 53,74 \\
\hline Всього & 366037 & 100 & 458682 & 100 & 566924 & 100 \\
\hline
\end{tabular}

Джерело: складено автором на основі [4-6]

Таблиця 3

Склад та структура податкових надходжень місцевих бюджетів України за 2016-2018 рр.

\begin{tabular}{|c|c|c|c|c|c|c|}
\hline \multirow{3}{*}{ Податкові надходження } & \multicolumn{6}{|c|}{ Роки } \\
\hline & \multicolumn{2}{|c|}{2016} & \multicolumn{2}{|c|}{2017} & \multicolumn{2}{|c|}{2018} \\
\hline & млн. грн. & $\begin{array}{l}\text { питома } \\
\text { вага,\% }\end{array}$ & млн. грн. & $\begin{array}{l}\text { питома } \\
\text { вага,\% }\end{array}$ & млн. грн. & $\begin{array}{l}\text { питома } \\
\text { вага,\% }\end{array}$ \\
\hline Податок на доходи фрізичних осіб & 78971 & 53,76 & 110653 & 55,05 & 135647 & 59,02 \\
\hline Податок на прибуток підприємств & 5879 & 4,00 & 6485 & 3,23 & 8782 & 3,82 \\
\hline $\begin{array}{l}\text { Рентна плата та плата за використання } \\
\text { інших природних ресурсів }\end{array}$ & 1082 & 0,74 & 1103 & 0,55 & 2878 & 1,25 \\
\hline Внутрішні податки на товари та послуги & 11628 & 7,92 & 13156 & 6,55 & 13623 & 5,93 \\
\hline Місцеві податки та збори & 42261 & 28,77 & 52587 & 26,16 & 58902 & 25,63 \\
\hline Інші податки та збори & 7080 & 4,81 & 17021 & 8,46 & 9982 & 4,35 \\
\hline Всього & 146902 & 100 & 201005 & 100 & 229815 & 100 \\
\hline
\end{tabular}

Джерело: складено автором на основі [4-6] 
загалом суперечить впровадженій реформі децентралізації. Адже чим вищою часткою міжбюджетних трансорертів характеризуватиметься дохідна частина місцевих бюджетів, тим більш централізована система, а також більша залежність органів місцевої влади.

Tому в сучасних умовах питання визначення впливу процесів бюджетної децентралізації залишається неоднозначним. Оскільки важливою передумовою есрективного соціально-економічного розвитку регіонів та належного функціонування місцевого самоврядування $€$ наявність достатніх обсягів власної ресурсної бази для надання якісних суспільних благ та послуг безпосередньо споживачам.

Висновки з проведеного дослідження. Таким чином, незважаючи на позитивні аспекти реформи децентралізації, успішній та повноцінній її реалізації в Україні передують проблеми, що стосуються питань фрормування місцевих бюджетів. Зокрема, такими є: все ще високий рівень централізації в управлінні бюджетними ресурсами органів місцевого самоврядування; недостатні обсяги власної дохідної бази місцевих бюджетів, що не дозволяє місцевим органам влади повною мірою фрінансувати всі видатки, пов'язані із виконанням їхніх повноважень; відповідно значна дотаційність місцевих бюджетів, що справляє загалом негативний вплив на забезпечення ефективного сталого розвитку регіонів; незацікавленість місцевих органів влади у збільшенні надходжень до відповідних бюджетів та пошуку додаткових джерел надходжень тощо.

Проте, попри наявні проблеми та ризики, що виникають у процесі здійснення бюджетних трансорормацій в частині розподілу повноважень між органами управління різних рівнів, зниження якості управлінських рішень на місцевому рівні, посилення ролі місцевих бюджетів у забезпеченні фрінансової самостійності місцевих органів доцільним є здійснення низки взаємопов'язаних заходів щодо подальшого успішного впровадження бюджетної децентралізації. В тому числі це:

- законодавчо закріплений чіткий розподіл власних і делегованих повноважень та фрункцій місцевих органів влади, що впливатиме на зростання рівня та якості надання суспільних благ та послуг на локальному рівні із відповідним фрінансовим забезпеченням діяльності;

- утвердження спроможності органів місцевого самоврядування щодо встановлення та оптимізації переліку місцевих податків і зборів, їхніх ставок у відповідності до особливостей розвитку певної території для фрінансування потреб безпосередніх споживачів;

- підвищення ефективності прийняття управлінських рішень на місцевому рівні, а також посилення зацікавленості місцевих органів влади у збільшенні власного ресурсного потенціалу із використанням новітніх та прогресивних інстру- ментів впливу територіальних громад на економічне зростання відповідного регіону;

- посилення прозорості щодо фрормування та використання коштів місцевих бюджетів.

\section{БІБЛІОГРАФІЧНИЙ СПИСОК:}

1. Бюджетний кодекс України від 08.07.2010 № 2456-VI. База даних «Законодавство України». URL: http://zakon2.rada.gov.ua/laws/show/2456-17. (дата звернення: 01.10.2019).

2. Дем'янюк А. В. Формування місцевих бюджетів в умовах здійснення реформи децентралізації. Економіка. Фінанси. Право. 2016. № 11. С. 23-25.

3. Загородній А.Г., Вознюк Г.Л., Смовженко Т.С. Фінансовий словник. К.: Т-во «Знання», КОО; Л.: Вид-во Львів. банк. Ін.-ту НБУ. 2002. 566 с.

4. Річний звіт про виконання Державного бюджету України за 2016 рік. URL: https://www.treasury.gov.ua/ ua/file-storage/richniy-zvit-pro-vikonannyaderzhavnogo-byudzhetu-ukraini-za-2016-rik?page=1 (дата звернення: 14.10.2019).

5. Річний звіт про виконання Державного бюджету України за 2017 рік. URL: https://www.treasury.gov.ua/ ua/file-storage/richniy-zvit-pro-vikonannyaderzhavnogo-byudzhetu-ukraini-za-2017-rik (дата звернення: 14.10.2019).

6. Річний звіт про виконання Державного бюджету України за 2018 рік. URL: https://www.treasury.gov.ua/ ua/file-storage/richnij-zvit-pro-vikonannyaderzhavnogo-byudzhetu-ukrayini-za-2018-rik (дата звернення: 14.10.2019).

7. Кириленко О., Лучка А. Зміцнення фрінансових основ місцевого самоврядування в Болгарії та Польщі: досвід реформ та висновки для України. Світ фонансів. 2007. № 3. С. 16-31.

8. Лопушняк Г., Лободіна 3., Ливдар М. Фіскальна децентралізація в Україні: декларації та практична реалізація. Економічний часопис-XXI. 2016. № 161 (9-10). С. 79-84.

9. Серьогін С.С. Рефрормування місцевих фрінансів в умовах євроінтеграції. Аспекти публічного управління. Вип. 30-31. 2016, С. 87-96.

10. Про добровільне об'єднання територіальних громад: Закон України від 5.02.2015 №157-VIII. Дата оновлення: 01.01.2019 URL: https://zakon.rada.gov.ua/ laws/show/157-19 (дата звернення: 20.10.2019).

11. Про Стратегію сталого розвитку «Україна - 2020»: Указ Президента України від 12.01.2015 №5/2015. Дата оновлення: 12.01.2015. URL: https:// zakon1.rada.gov.ua/laws/show/5/2015 (дата звернення: 14.10.2019).

12. Про схвалення Концепції реформування місцевого самоврядуваннятатериторіальної організації влади в Україні: Розпорядження Кабінету Міністрів України від 1 квітня 2014 р. № 333-р. Дата оновлення: 01.04.2014. URL: https://zakon.rada.gov.ua/laws/show/333-2014-\%D1 \%80\#n8 (дата звернення: 14.10.2019).

13. Структура зведеного бюджету України за 2016-2018 рр. Ціна держави. URL: http://cost.ua/ budget/revenue/ (дата звернення: 22.10.2019).

14. Сунцова О.О. Місцеві фрінанси: навчальний посібник. Київ: Центр навчальної літератури, 2010. 488 с. 
15. Усков И.В. Децентрализация как основа становления фринансово самостоятельних местных органов власти. Бізнес Інфрорм. № 3. 2012. С. 107-111.

\section{REFERENCES:}

1. Biudzhetnyi kodeks Ukrainy (2010 July 8, № 2456VI). Baza danykh «Zakonodavstvo Ukrajiny» Available at: http://zakon2.rada.gov.ua/laws/show/2456-17 (accessed 1 October 2019).

2. Demianiuk A.V. (2016) Formuvannia mistsevykh biudzhetiv $v$ umovakh zdiisnennia reformy detsentralizatsii [Formation of local budgets in the context of decentralization reform]. Ekonomika. Finansy. Pravo, no. 11, pp. 23-25.

3. Zahorodnii A.H., Vozniuk H.L., Smovzhenko T.S. (2002) Finansovyi slovnyk [Financial dictionary]. K.: T-vo «Znannia», KOO; L.: Vyd-vo Lviv. bank. In.-tu NBU. (in Ukrainian)

4. Richnyi zvit pro vykonannia Derzhavnoho biudzhetu Ukrainy za 2016 rik. (2016) Available at: https://www.treasury.gov.ua/ua/file-storage/richniy-zvitpro-vikonannya-derzhavnogo-byudzhetu-ukraini-za2016-rik?page=1 (accessed 14 October 2019).

5. Richnyi zvit pro vykonannia Derzhavnoho biudzhetu Ukrainy za 2017 rik. (2017) Available at: https://www.treasury.gov.ua/ua/file-storage/richniy-zvitpro-vikonannya-derzhavnogo-byudzhetu-ukraini-za2017-rik (accessed 14 October 2019).

6. Richnyi zvit pro vykonannia Derzhavnoho biudzhetu Ukrainy za 2018 rik. (2018) Available at: https://www.treasury.gov.ua/ua/file-storage/richnij-zvitpro-vikonannya-derzhavnogo-byudzhetu-ukrayini-za2018-rik (accessed 14 October 2019).

7. Kyrylenko O., Luchka A. (2007) Zmitsnennia finansovykh osnov mistsevoho samovriaduvannia $v$ Bolharii ta Polshchi: dosvid reform ta vysnovky dlia Ukrainy [Strengthening the financial bases of local selfgovernment in Bulgaria and Poland: reform experiences and lessons learned for Ukraine]. Svit finansiv, no. 3, pp. 16-31. (in Ukrainian)

8. Lopushniak H., Lobodina Z., Lyvdar M. (2016) Fiskalna detsentralizatsiia v Ukraini: deklaratsii ta praktychna realizatsiia [Fiscal decentralization in Ukraine: declarations and practical implementation]. Ekonomichnyi chasopys-XXI, no. 161(9-10), pp. 79-84.

9. Serohin S.S. (2016) Reformuvannia mistsevykh finansiv $v$ umovakh yevrointehratsii [Reforming local finances in the context of European integration]. Aspekty publichnoho upravlinnia, vol. 30-31, pp. 87-96.

10. Pro dobrovilne obiednannia terytorialnykh hromad: Zakon Ukrainy vid 5.02.2015 №157-VIII. Data onovlennia: 01.01.2019 Available at: https://zakon.rada.gov.ua/ laws/show/157-19 (accessed 20 October 2019).

11. Pro Stratehiiu staloho rozvytku «Ukraina-2020»: Ukaz Prezydenta Ukrainy vid 12.01.2015 №5/2015. Data onovlennia: 12.01.2015. Available at: https:// zakon1.rada.gov.ua/laws/show/5/2015 (accessed 20 October 2019).

12. Pro skhvalennia Kontseptsii reformuvannia mistsevoho samovriaduvannia ta terytorialnoi orhanizatsii vlady v Ukraini: Rozporiadzhennia Kabinetu Ministriv Ukrainy vid 1 kvitnia 2014 r. №333-r Data onovlennia: 01.04.2014. Available at: https://zakon.rada.gov.ua/ laws/show/333-2014-\%D1\%80\#n8 (accessed 20 October 2019).

13. Struktura zvedenoho biudzhetu Ukrainy za 2016-2018 rr. Cina derzhavy URL: http://cost.ua/budget/revenue (accessed 22 October 2019).

14. Suntsova O.O. (2010) Mistsevi finansy [Local finance]: navchaljnyj posibnyk. Kyiv: Tsentr navchalnoi literatury. (in Ukrainian)

15. Uskov Y.V. (2012) Detsentralyzatsyia kak osnova stanovlenyia fynansovo samostoiatelnykh mestnыkh orhanov vlasty [Decentralization as the basis for the formation of financially independent local authorities]. Biznes Inform, no. 3, pp. 107-111. (in Russian) 
Savchuk Svitlana

Candidate of Economic Sciences, Associate Professor, Senior Lecturer at S.I. Yurii Finance Department Ternopil National Economic University

\section{FORMATION OF LOCAL BUDGET REVENUES IN CONDITIONS OF BUDGETARY DECENTRALIZATION}

Effective levers of successful implementation of the decentralization reform are budgetary instruments aimed at solving strategic and current tasks of consolidation of the financial independence of local governments, strengthening the financial sustainability of local budgets, creating favourable conditions for the development of local infrastructure etc. At the same time, the issues concerning the formation of the relevant resource base for the fulfillment of the functions entrusted on local authorities, the achievement of the main goals for the development of the region, which are outlined in particular programs, to maximize the satisfaction of the population with qualitative public goods become especially topical for solving specified tasks.

Although Ukraine initiated the focus on decentralization in 2014, the problems of financial support of local governments, constant lack of financial resources, instability of revenue sources of local budgets and their dependence on fiscal transfers as well as low level of availability of local public goods etc. go unaddressed. Thus, further application of effective measures on the modernization of the formation of local budgets in the context of budget decentralization by local government will contribute to the activation of the reform and effective development of the institute of local government.

The research goal is to define the impact of the budget decentralization on the process of forming local budget revenues and to substantiate the need of its further reforming in the current context.

Research methods are based on the method of scientific knowledge and systems approach to studying the issues of the generation of local budget revenues under the conditions budget decentralization, method of economics and statistics analysis for studying the practice of forming the revenue of local budgets.

A pivotal role for the implementation of the policy of decentralization of power in the country belongs to the very process of distributing the functions and powers between state and local authorities to provide citizens with necessary public goods and services and to divide financial resources to the extent sufficient to finance the powers of the local authority.

In the current context, the issue of budget decentralization and effective organization of inter-budgetary relations in Ukraine are top-priority because they are the main factor for the financial independence and sustainability of local governments. The very decentralization of the process of making managerial decisions contributes to increasing the capacity of local authorities to participate in the development of a particular area, and budget decentralization facilitates the provision of the population with public services through a clear approval of expenditures for authorities at different levels according to local needs and requirements.

In 2014, Ukraine initiated a reform of budget decentralization which aims to improve financial independence local authorities and broaden their powers. Consequently, under the framework of focus on the decentralization of the budget system, scholars and practitioners concentrate on the issue of formation of local budget revenues.

In general, transformation processes showed a positive effect on the formation of local budget revenues that respectively reflects its annual growth not only through inter-budgetary transfers but also through revenue increase. However, it is not unlikely that local budgets are still sufficiently dependent on the volume of transfers from the state budget, which account for about half of the revenues. The above refers to their significant dependence on the state budget that generally contradicts to the implemented decentralization reform. Thus, the higher stake of inter-budgetary transfers of local budget revenues, the system is more centralized, and the dependence of local authorities is more.

Therefore, in the current context, the issue of determining the impact of budget decentralization processes remains ambiguous. The availability of sufficient volumes of the own funding base to provide consumers with qualitative public goods and services is an important precondition for effective socio-economic development of the regions.

However, despite the available problems and risks originating in the process of budgetary transformations in terms of the distribution of powers between government agencies of different levels, reducing the quality of management decisions at the local level, enhancing the role of local budgets in ensuring the financial autonomy of local authorities, it is expedient to carry out some interrelated actions towards further successful implementation of budget decentralization. Encouragement of local authorities for the improvement of their funding base, including reducing of the provision of central-level transfers for the socio-economic development of certain territories, is the important measure for ensuring the autonomy and financial independence of local budgets. 